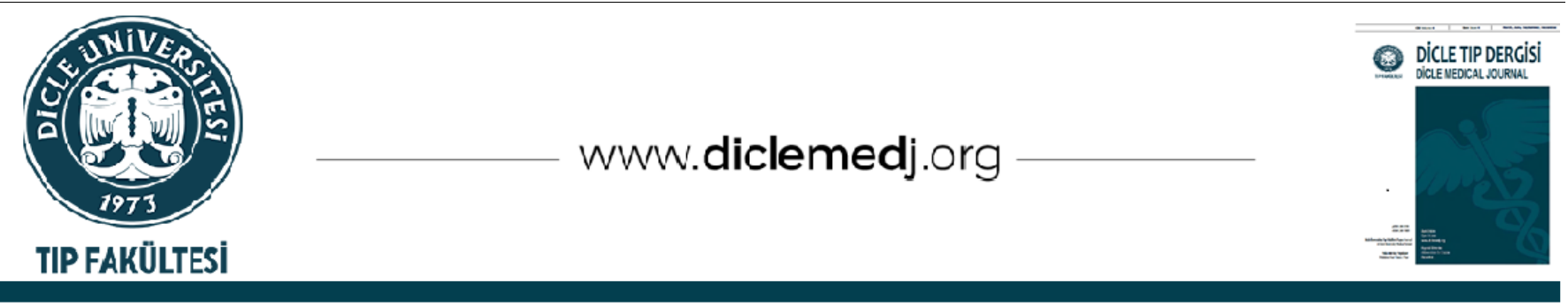

Derleme / Review

\title{
COVID-19 ve Nöroloji
}

\author{
Ünal Öztürk ${ }^{i} 1_{1}$ Yusuf Tamam ${ }^{D_{2}}$ \\ 1 Sağlık Bilimleri Üniversitesi, Gazi Yaşargil Sağlık Uygulama ve Araştırma Merkezi, Nöroloji Bölümü, Diyarbakır, Türkiye \\ 2 Dicle Üniversitesi Tıp Fakültesi, Nöroloji Anabilim Dalı, Diyarbakır, Türkiye
}

Geliş: 11.09.2021; Kabul Tarihi: 29.09.2021

$\ddot{0} \mathbf{z}$

Amaç: COVID-19 (SARS-CoV-2) pandemisi bütün hasta gruplarını etkilediği gibi nörolojik hastalıkları olan bireyleri de etkilemiştir. Mevcut pandemi koşullarında hem tedaviye ulaşımın güçleşmesi hem de stres faktörlerinin artışı nedeniyle kronik nörolojik bozukluğu olan hasta gruplarının yönetimi için kılavuzlara ihtiyaç duyulmaktadır. Bu yazı ile Covid-19 pandemisi sürecinde kronik nörolojik bozukluğu olan hasta gruplarında tedavi ve takip sürecini kolaylaştıracak bilgilere yer verilmesi planlanmıştır.

Sonuç: Nörolojik hastalıkları olan hastaların tedavilerini nörolog kontrolü altında devam ettirmeleri, tedavi değişikliği ve tedavinin kesilmesi sürecine nöroloji uzmanının karar vermesi önerilir. Halk sağlığı önerilerine uymaları, gereklilik halinde teletıp sisteminden yararlanmaları önerilir.

Anahtar kelimeler; Nörolojik hastalıklar, COVİ-19, multipl skleroz, nöromüsküler hastalıklar, epilepsi

\section{COVID-19 and Neurology}

\section{Abstract}

Objective: The COVID-19 (SARS-CoV-2) pandemic has affected all patient groups as well as individuals with neurological diseases. In the current pandemic conditions, there is a need for guidelines for the management of patient groups with chronic neurological disorders due to both the difficulty in accessing treatment and the increase in stress factors. With this article, it is planned to include information that will facilitate the treatment and follow-up process in patient groups with chronic neurological disorders during the Covid-19 pandemic.

Conclusion: It is recommended that patients with neurological diseases continue their treatment under the control of a neurologist, and the neurologist must decide on the process of changing treatment and discontinuing the treatment. It is recommended that they comply with public health recommendations and benefit from the telemedicine system if necessary.

Keywords; Neurological disease, COVID-19, multiple sclerosis, neuromuscular disease, epilepsy.

DOI: 10.5798/dicletip.1004787

Yazışma Adresi / Correspondence: Ünal Öztürk, Sağllk Bilimleri Üniversitesi Gazi Yaşargil Sağlık Uygulama ve Araștırma Merkezi, Nöroloji Bölümü Diyarbakır, Türkiye e-mail: drunalozturk@gmail.com 


\section{GíRiş}

COVID-19 (SARS-CoV-2) pandemisi bütün hasta gruplarını etkilediği gibi nörolojik hastalıkları olan bireyleri de etkilemiştir ${ }^{1}$. Mevcut pandemi koşullarında hem tedaviye ulaşımın güçleşmesi hem de stres faktörlerinin artışı nedeniyle kronik nörolojik bozukluğu olan hasta gruplarının yönetimi için kılavuzlara ihtiyaç duyulmaktadır². Bu yazı ile Covid-19 pandemisi sürecinde kronik nörolojik bozukluğu olan hasta gruplarında tedavi ve takip sürecini kolaylaştıracak bilgilere yer verilmesi planlanmıştır.

\section{Multipl Skleroz}

Multipl Skleroz (MS), nöroinflamatuar bir hastalık olup immünoterapinın sık kullanımı ve yutma/solunum problemleri nedeniyle risk teşkil eden bir hastalıktır. Bağışıklık sisteminin baskılanmış olmasının yanı sıra pandemi nedeniyle tedaviye ulaşım güçlügü ve basında çıkan haberler hastaların stresini arttırmaktadır ${ }^{3}$.

Hastalar, enfeksiyon riski korkusu nedeniyle immünoterapilerini bırakmaya meyillidir, ancak doktorlar ve dernekler arasındaki genel fikir birliği, ilaçta değişiklik yapılmasının nörologlarına danışmadan yapılmaması gerektiğidir ${ }^{4}$. Hastalığın seyrini değiştiren ilaçların çoğu, bağışıklık sistemini baskılama veya modüle etme prensibiyle çalışır. $\mathrm{Bu}$ nedenle, bazı MS ilaçları COVID-19'dan kaynaklanan komplikasyon olasılığını artırabilir. $\quad \mathrm{Bu}$ tedavinin kesilmesi/sonlandırılması/başlanmaması, her zaman belirli bir ilacın etki mekanizmasına karşı MS aktivitesi riskine göre bireysel olarak düşünülmelidir ${ }^{5}$.

MS hastalarının takipleri için teletıptan faydalanmaları ancak transfüzyon ve atak araştırmaları için hastanelere başvurmaları hasta yönetiminde yardımcı olabilir6. Bununla birlikte, COVID-19 pozitif hastaların bilișsel sağlığı ve COVID-19'un neden olduğu enfeksiyonun MS'in şiddetini ve/veya dolayısıyla ilişsili artan beyin atrofisi oranını hızlandırıp hızlandırmayacağı henüz bilinmemektedir ${ }^{1}$.

\section{Viral enfeksiyon riskine karşı MS hastaları için öneriler;}

- Hastalar rebound fenomeninden kaçınmak için tedaviyi kendileri bırakmamalıdır.

- Aşağıdaki ilaçlar genellikle bağışıklık yanıtının önemli ölçüde baskılanmasına yol açmaz ve olağan protokollere göre reçete edilebilir:

o Glatiramer asetat

o Beta interferonlar

o Teriflunomid

o Dimetil fumarat

o Solumedrol

- Așağıda listelenen ilaçlar hafif derecede riskli olabilir (Rebound fenomeni nedeniyle bu ilaçların bırakılmaması önerilir).

o Fingolimod

o Natalizumab

o Okrelizumab

o Rituksimab

- Așağıda listelenen ilaçlar söz konusu olduğunda bunların düzenli uygulanması/tedaviye başlanması dikkatli bir değerlendirmeye tabi tutulmalıdır. Bireysel durumlar her zaman ilgili hekime danışılmalıdır. Yüksek MS aktivitesi ile hastalık aktivitesi riskini ve MS'e bağlı olarak hastaya geri dönülemez zarar verme olasılığını hesaba katmak gerekir.

o Kladribin

o Alemtuzumab5. 


\section{Nöromüsküler Hastalıklar}

COVID-19'un nöromüsküler hastalıkların alevlenme ve ilerlemesine sebep olabileceği gibi yeni nöromüsküler hastalıklara da sebep olabileceği düşünülmektedir ${ }^{7}$.

Etiyolojisinde viral enfeksiyonların suçlandığı Guillain-Barre'sendromunun (GBS) COVID-19 sonrası da görüldüğü bildirilen olgular mevcuttur ${ }^{8}$. Spesifik viral proteinler ile periferik sinir üzerindeki proteinler arasındaki moleküler benzerliğin olması ve bunun da periferik sinirlerin miyelin ve aksonuna karşı saldırısına yol açmasıdır.

Bazı viral enfeksiyonlarda görüldüğü gibi motor nöronların ve periferik sinirlerin inflamasyonu ve dejenerasyonu ile doğrudan viral invazyona bağlı miyozit görülebilir. COVID-19 çalışmalarında miyalji ve kreatin kinaz artışı görüldüğü bildirilmektedir. Özellikle kritik hastalıkları olan gruplarda miyopati ve polinöropati gelişebileceği konusunda dikkatli olmak gerekir?

Enfeksiyon, hem kalıtsal hem de immün aracılı birçok nöromüsküler hastalıkta alevlenme ve hastalığın ilerlemesi için tetikleyici faktördür9. $\mathrm{Bu}$ durum göz önüne alındığından nöromüsküler hastalıkları olan hastaların yüksek COVID-19 enfeksiyonu riski altında olduğu düşünülmektedir. Şu anda COVID-19'un motor nöron hastalığı (MND), miyastenia gravis (MG), otoimmün veya inflamatuar nöropatiler veya inflamatuar miyopatiler vb. dahil olmak üzere nöromüsküler bozuklukları olan kişileri nasıl etkilediğine dair hiçbir veri bulunmamaktadır. Bunun, immünosupresif tedavi alan hastaları nasıl etkileyeceği konusunda net bir kllavuz yoktur. İmmünosupresif tedaviler alan ve/veya MG veya Lambert Eaton miyastenik sendromu gibi bulbar/solunum kası zayıflı̆̆ı olan hastaların enfeksiyona yakalanma veya COVID-19'un şiddetli belirtilerini yaşama riskinin daha yüksek olduğunu varsaymamız gerekir ${ }^{10}$.
Nöromüsküler hastalıkları olan hastalara halk sağlığı önlemlerine uymaları önerilir. Tedavi rejiminde / dozajında herhangi bir değișiklik sadece tedavi eden doktorun tavsiyesi ve onayı ile yapılmalıdır ${ }^{11}$.

İmmünsüpresif tedaviler kullanan nöromüsküler hastalığı olan hastalar, muhtemelen COVID-19'a yakalanma veya daha şiddetli bir virüs seyrine sahip olma riski altındadır. Bu risk, immünsüpresif tedavi alan ve aynı hastalığı olan hastalar arasında bile değişkendir. Riski etkileyen faktörler arasında immünterapi, birden fazla ajanla immünsüpresyon, yüksek doz tedavi, yüksek derecede aktif immün aracılı nöromüsküler hastalık, yutma ve solunum sorunları, pulmoner hipertansiyon, renal-hepatik bozukluklar, diabetes mellitus vs. ${ }^{12}$. Ancak bazı tedavilerin COVİ-19'un ağır geçmesi ile ilgili riski arttırması beklenmez; immünglobulin tedavileri, kompleman inhibitör tedavileri, terapötik plazma değişimi, neonatal Fc reseptör antagonistleri gibi13.

Halihazırda non-invaziv ventilasyon (NIV) veya iki düzeyli pozitif hava yolu basıncı (BiPAP) kullanan hastaların kişisel solunum ekipmanının düzenli olarak temizlenmesi ve bakımının yapılması esastır. BiPAP'a bağımlı olan nöromüsküler hastaların hastanede yatması gerekebileceği göz önünde bulundurulmalıdır ${ }^{1}$.

\section{COVID-19 ilişkili potansiyel nöromüsküler komplikasyonlar;}

- Enfeksiyona bağlı yeni gelişen nöromüsküler hastlalık (GBS, miyozit, miyopati veya nöropati

- Mevcut nöromüsküler hastalığın alevlenmesi veya ilerlemesi (otoimmün veya dejeneratif hastalıklar)

- Otoimmün nöromüsküler hastalıklarda immünsüpresif / immünmodulatör tedavi 
- COVID-19 tedavisi için kullanılan ilaçlarla ilişkili risk faktörleri (klorokin / antiviral ilaç ilişkili nöropati-miyopati)

- Așı riskleri (olası inflamatuvar nöropati)7.

\section{Epilepsi}

Epilepsili hastaların hastalığa karşı genel popülasyondan daha savunmasız olup olmadığ konusunda çeliş̧ili görüşler vardır ${ }^{14}$. Bazı epilepsi kuruluşları bu popülasyonu özellikle savunmasız olarak görmese de, epilepsili hastaların sunumlarının çok çeşitli olduğunu ve epilepsi hastalarının önemli bir bölümünün ( \%80) düşük veya orta gelirli bir ülkede yaşadığını bilmek önemlidir ${ }^{15}$. Ateş ve enfeksiyon tarafindan tetiklenen nöbetleri olan hastalar nispeten daha yüksek risk altında kabul edilebilir ve ateş gelişirse ateş düşürücü almayı düşünebilirler. Tipik antiepileptik ilaçlar bağışıklık sistemini baskılamadığından, hastaların anti-epileptik ilaçlarını COVID-19 korkusu nedeniyle birakmamaları zorunludur ${ }^{16}$.

Yapılan çalışmalarda \%8,6 ile \%29,5 arasında değişen oranlarda nöbetlerde kötüleşme olduğu belirtilmiştir. Bunun nedenleri olarak da; antiepileptik ilaç sayısı, nöbet sıklığı, ilaç rejimine uyumsuzluk, uyku düzeninde değişiklik, streste artış, COVID-19'a maruz kalma, ilaca dirençli epilepsi, epilepsi etiyolojisi olan hastalığın tedavisine ulaşamama (tümör gibi), gelirin düşmesi ile ilaç temininde güçlük gösterilmiştir ${ }^{17}$.

\section{Hareket Bozuklukları}

Parkinson Hastalığı (PH) olan hastalar, kendi başına daha yüksek risk altında olmasalar da, potansiyel COVID-19'a maruz kalmalarını en aza indirmek için alınan önlemler açısından, ileri yaş, bulbar semptomlar, solunum fonksiyon bozukluğu, frajilite ve bilişsel bozulma nedeniyle savunmasız bir popülasyon olarak kabul edilmelidir18. PH'li hastaların pnömoni geliştirme olasılığı daha yüksektir ve enfeksiyonlar ani motor ve bilişsel değişikliklere neden olabilir. Bu nedenle COVID19 hastalarını tedavi eden sağlık çalışanları, potansiyel deliryum vakalarına hazırlıklı olmanın yanı sıra PH hastalarını yönetmek için donanımlı olmalıdır ${ }^{19}$.

COVID-19 motor semptomlarda kötüleşmeye neden olabilir. Akut sistemik inflamatuvar yanıta veya farmakokinetik değişikliklere bağlı ilaç etkinliğinin azalması sonrası levodopaya yanıtlı motor semptomlarda kötüleşme ve günlük OFF zamanlarında artış görülebilir. $\mathrm{Bu}$ durumlarda ilaç düzeyinin arttırılabileceği akılda tutulmalıdır. Nonmotor semptomlarda artış olabilir. Yapılan çalışmalarda enfeksiyon kaynaklı idrar inkontinansı ve noktüride artış olduğu ancak kardiyovasküler, gastrointestinal ve seksüel fonksiyonlarda değişiklik olmadığı bildirilmiştir ${ }^{20}$.

\section{İnme}

COVID-19'da büyük damarlar oklüzyonu, çok bölge inme ve nadir etkilenen damarda inmeye eğilim artmıştır. COVID-19 ilişkili iskemik inme patogenezi net olmamakla birlikte sitokin firtınası ve endotelyopati suçlanmaktadır ${ }^{21}$. Çalışmalar özellikle asemptomatik veya hafif semptomatik genç COVID-19 olgularında büyük damarların etkilendiği inmelere sebep olduğunu göstermiştir ${ }^{22}$.

Çalışmalar inme hastalarının COVID-19 riski nedeniyle hastaneye başvurusunun özellikle ileri yaş grubunda azaldığını göstermiştir ${ }^{23}$. Daha önce inme geçirmiş hastaların hastane başvurularının azaldığı, hastane iletişiminin Teletıp üzerinden sağlandığı gözlenmiştir ${ }^{1}$. Hastalar ayrica COVID-19'a yakalanma durumunda ciddi pnömoniye nispeten daha duyarlıdır. Enfeksiyon riskinin artışı birebir inme ile ilişkilendirilmese de inme hastaların etiyolojisinde sık görülen hipertansiyon, diyabetes mellitus ve kardiyovasküler hastalıkların riski arttırdığı düşünülmektedir ${ }^{24}$. 
İnme sonrası kullanılan ilaçların COVID-19 enfeksiyonu riskini arttırması beklenmediğinden ilaç rejiminin değiștirilmesine gerek yoktur ${ }^{1}$.

İnme sonrası rehabilitasyon sürecindeki hastaların pandemi koşulları altında etkin rehabilitasyona ulaşımının azalması nedeniyle ev egzersiz programları ile desteklenmeleri gereklidir ${ }^{24}$.

\section{Demans}

Alzheimer hastalığı ve ilgili demansı olan hastalar, artan COVID-19 enfeksiyon riski ve bununla ilişkili morbidite ve mortalite riski altındadır. Demansı olan hastaların halk sağlığı kısitlamalarina ve tavsiyelerine uyma olasılıkları daha düşüktür. Demans hastalarında kardiyovasküler hastalık, diyabet ve pnömoni prevalansı daha yüksektir ve bu da COVID-19 enfeksiyonundan sonra ciddi hastalık riski olasılığını arttırır ${ }^{25}$. Sağlık hizmetleri üzerindeki baskl, Alzheimer ve diğer demans hastalarının teşhisini ve klinik yönetimini de olumsuz etkilemiştir. Bakım evlerinde bulunan hastalar enfeksiyon salgınına karşı özellikle savunmasızdır. Bazı hükümetler, ziyaretler konusunda katı kisitlamalar getirse de bu, hastalar arasinda daha fazla sosyal izolasyona ve strese yol açmıştır ${ }^{26}$. Hastaların teletıp yoluyla yakından izlenmesi gereklidir. Akut bir olay geliştirme "yüksek risk" altında olan hastaların belirlenmesi ve bazı ilaçların riskfayda oranının sürekli olarak değerlendirilmesi bir önceliktir ${ }^{25}$.

Sonuç olarak; kronik nörolojik hastalıkları olan hastalar, kısıtlanmış mobilizasyonu olan ve bakım desteği almak zorunda olan bireyler olabileceğinden genel olarak kronik nörolojik hastaların, özellikle de bağışıklık sistemi baskılanmış rahatsızlıkları olanların kendilerini izole etmeleri ve pandemi kaynaklı kapanma devam ederken uzun süre yeterli ilaç tedarikinin mevcut olduğundan emin olmaları önerilir. Mevcut tedavilerindeki değişikleri hekim kontrolünde yapmaları önerilir.

Çıkar Çatışması Beyanı: Yazarlar çıkar çatışması olmadığını bildirmişlerdir.

Finansal Destek: Bu çalışma her hangi bir fon tarafından desteklenmemiştir.

Declaration of ConflictingInterests: The authors declare that they have no conflict of interest.

Financial Disclosure: No financial support was received.

\section{KAYNAKLAR}

1. Bhaskar S, Bradley S, Israeli-Korn S, et al. Chronic Neurology in COVID-19 Era: Clinical Considerations and Recommendations From the REPROGRAM Consortium. Front Neurol. 2020; 11: 664. doi: 10.3389/fneur.2020.00664.

2. Helmich RC, Bloem BR. The impact of the COVID19 pandemic on Parkinson's disease: hidden sorrows and emerging opportunities. J Parkinsons Dis. 2020; 10: 351-4. doi: 10.3233/jpd-202038.

3. Powell J. I'm choosing to let my spirit shine during the COVID-19 crisis. Multiple Sclerosis News Today. 2020. Available online at: https://multiplesclerosisnewstoday.com/newsposts/2020/03/30/my-spirit shines-amid-covid19-a-choice-to-thrive-with-spms/ (accessed June 1, 2020).

4. Brownlee W, Bourdette D, Broadley S, Killestein J, Ciccarelli 0 . Treating multiple sclerosis and neuromyelitis optica spectrum disorder during the COVID-19 pandemic. Neurology. 2020; 94: 949-52. doi: 10.1212/wnl.0000000000009507.

5. Mares J, Hartıng HP. Multiple sclerosis and COVID19. Biomed Pap Med Fac Univ Palacky Olomouc Czech Repub. 2020; 164: 217-25.

6. National Multiple Sclerosis Society. MS Treatment Guidelines during Coronavirus. (2020). Available online at: https://www.nationalmssociety. org/coronavirus-covid-19-information/multiplesclerosis-and-coronavirus/ms- treatmentguidelines-during-coronavirus\#section- 
$0 \backslash$ relax\$\@@underline $\backslash$ hbox \{\}$\backslash$ mathsurround $\backslash \mathrm{z} @$ $\$ \backslash$ relax (accessed June 1, 2020).

7. Guidon AC, Amato AA. COVID-19 and neuromuscular disorders. Neurology. 2020;94:959969. doi:10.1212/WNL.0000000000009566.

8. Caress JB, Castoro RJ, Simmons Z, et al. COVID-19associated Guillain-Barré syndrome: The early pandemic experience. Muscle Nerve. 2020;62(4):485-491. doi: 10.1002/mus.27024. Epub 2020 Aug 11.

9. Gummi RR, Kukulka NA, Deroche CB, Govindarajan R. Factors associated with acute exacerbations of myasthenia gravis. Muscle Nerve. 2019; 60: 693-9.

10. Jacob S, Muppidi S, Guidon A, et al. Guidance for the management of myasthenia gravis (MG) and Lambert-Eaton myasthenic syndrome (LEMS) during the COVID-19 pandemic. J Neurol Sci. 2020; 412: 116803. doi: 10.1016/j.jns.2020.116803.

11. ALS Association. Coronavirus Disease Outbreak COVID-19. 2020. Available online at: http://www.alsa.org/assets/pdfs/COVID19_Facts.pdf (accessed April 5, 2020).

12. Huang C, Wang Y, Li X, et al. Clinical features of patients infected with 2019 novel coronavirus in Wuhan, China. Lancet. 2020; 395: 497-506.

13. Prompetchara E, Ketloy C, Palaga T. Immune responses in COVID-19 and potential vaccines: lessons learned from SARS and MERS epidemic. Asian Pac J Allergy Immunol. 2020; 38: 1-9.

14. Epilepsy Centre. Epilepsy and COVID-19. 2020. Available online at: https:// epilepsycentre.org.au/what- is- epilepsy/epilepsyand- covid- 19/ (accessed April 5, 2020).

15. Thijs RD, Surges R, O'Brien TJ, Sander JW. Epilepsy in adults. Lancet. 2019; 393:689-701. doi: 10.1016/s0140-6736 (18) 32596-0.

16. von Oertzen TJ, McGinty R, Holtkamp $M$, Kalviainen R, Ruegg S, Trinka E, Rubboli G. Impact of COVID-19 on management of epilepsy. European Association of Neurologists. 2020. Available online at: https://www.eanpages.org/2020/ 04/03/impact- of- covid- 19- on- management- ofepilepsy/ (accessed April 5, 2020).
17. Kuroda N. Epilepsy and COVID-19: Updated evidence and narrative review. Epilepsy Behav. 2021 Mar; 116: 107785.

18. Association APD. COVID-19 Overview for the Parkinson's Community. 2020. Available online at: https://www.apdaparkinson.org/article/covid-19overview-for-pd-community/ (accessed April 5, 2020).

19. Kotfis K, Williams Roberson S, Wilson JE, et al. COVID-19: ICU delirium management during SARSCoV-2 pandemic. Critical Care. 2020; 24: 176. doi: 10.1186/s13054-020-02882-x.

20. Cilia R, Bonvegna S, Straccia G, et al. Effects of COVID-19 on Parkinson's Disease Clinical Features: A Community-Based Case-Control Study. Mov Disord. 2020; 35: 1287-92. doi: $10.1002 /$ mds.28170.

21. Vogrig A, Gigli GL, Bnà C, Morassi M. Stroke in patients with COVID-19: Clinical and neuroimaging characteristics. Neurosci Lett. 2021; 743: 135564. doi: 10.1016/j.neulet.2020.135564.

22. Oxley TJ, Mocco J, Majidi S, et al. Large-vessel stroke as a presenting feature of Covid-19 in the Young. N Engl J Med. 2020; 382: e60. doi: 10.1056/NEJMc2009787.

23. Rudilosso S, Laredo C, Vera V, et al. Acute Stroke Care Is at Risk in the Era of COVID-19: Experience at a Comprehensive Stroke Center in Barcelona. Stroke. 2020; 51: 1991-5. doi: 10.1161/STROKEAHA.120.030329.

24. Wang CC, Chao JK, Wang ML, et al. Care for Patients with Stroke During the COVID-19 Pandemic: Physical Therapy and Rehabilitation Suggestions for Preventing Secondary Stroke. J Stroke Cerebrovasc Dis. 2020; 29: 105182. doi: 10.1016/j.jstrokecerebrovasdis. 2020. 105182.

25. Brown EE, Kumar S, Rajji TK, Pollock BG, Mulsant $\mathrm{BH}$. Anticipating and mitigating the impact of the COVID-19 pandemic on Alzheimer's disease and related dementias. Am J Geriatr Psychiatry. 2020 Jul; 28: 712-21. doi: 10.1016/j.jagp.2020.04.010.

26. Wang H, Li T, Barbarino P, et al. Dementia care during COVID-19. Lancet. (2020) 395:1190-1. doi: 10.1016/S0140-6736 (20) 30755-8. 